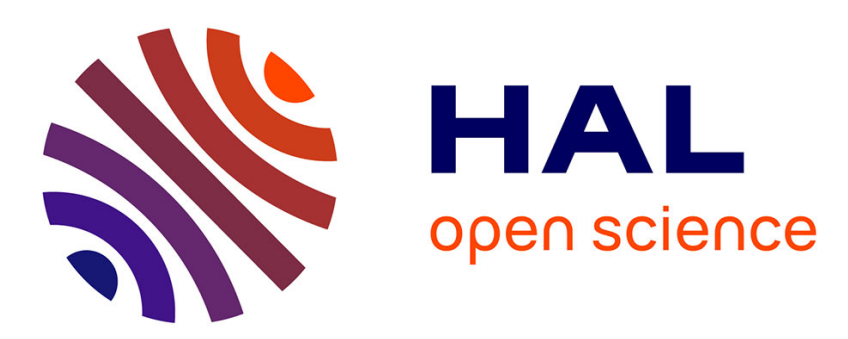

\title{
Cytotoxicity and cellular uptake of newly synthesized fucoidan-coated nanoparticles
}

M C B Lira, N S Santos-Magalhães, V Nicolas, V Marsaud, M P C Silva, Gilles Ponchel, Christine Vauthier

\section{- To cite this version:}

M C B Lira, N S Santos-Magalhães, V Nicolas, V Marsaud, M P C Silva, et al.. Cytotoxicity and cellular uptake of newly synthesized fucoidan-coated nanoparticles. European Journal of Pharmaceutics and Biopharmaceutics, 2011, 79 (1), pp.162 - 170. 10.1016/j.ejpb.2011.02.013 . hal-03206185

\section{HAL Id: hal-03206185 \\ https://hal.science/hal-03206185}

Submitted on 23 Apr 2021

HAL is a multi-disciplinary open access archive for the deposit and dissemination of scientific research documents, whether they are published or not. The documents may come from teaching and research institutions in France or abroad, or from public or private research centers.
L'archive ouverte pluridisciplinaire HAL, est destinée au dépôt et à la diffusion de documents scientifiques de niveau recherche, publiés ou non, émanant des établissements d'enseignement et de recherche français ou étrangers, des laboratoires publics ou privés. 


\title{
Cytotoxicity and cellular uptake of newly synthesized fucoidan- coated nanoparticles.
}

\author{
M.C.B. Lira ${ }^{1,2,5,6}$, N.S. Santos-Magalhães ${ }^{2,3}$, V. Nicolas ${ }^{4}$, V. Marsaud ${ }^{5,6}$, M.P.C. Silva ${ }^{2,3}$, G. \\ Ponchel $^{5,6}$, C. Vauthier ${ }^{5,6 *}$ \\ ${ }^{1}$ Centro de Ciências Biológicas, Universidade Federal de Pernambuco, Recife, Brasil, ${ }^{2}$ Laboratório de \\ Imunopatologia Keizo-Asami, Recife, Brasil, ${ }^{3}$ Departamento de Bioquímica,Universidade Federal de \\ Pernambuco, Recife, Brasil, ${ }^{4}$ Univ Paris Sud, Plateforme Imagerie Cellulaire, IFR 141, Faculté de Pharmacie, \\ Châtenay-Malabry, France, ${ }^{5}$ Univ Paris-Sud, Physico-chimie Pharmacotechnie Biopharmacie, UMR 8612, \\ Chatenay-Malabry , F-92296, ${ }^{6}$ CNRS, Chatenay-Malabry, F-92296
}

Published in: Eur J Pharm Biopharm 79 (2011) 162-170. https://doi.org/10.1016/j.ejpb.2011.02.013

*Corresponding author: Dr. Christine Vauthier, Université Paris-Sud, UMR 8612, 5 Rue J.B. Clément, F-92296 Chatenay-Malabry Cedex, France, E-mail: christine.vauthier@u-psud.fr.

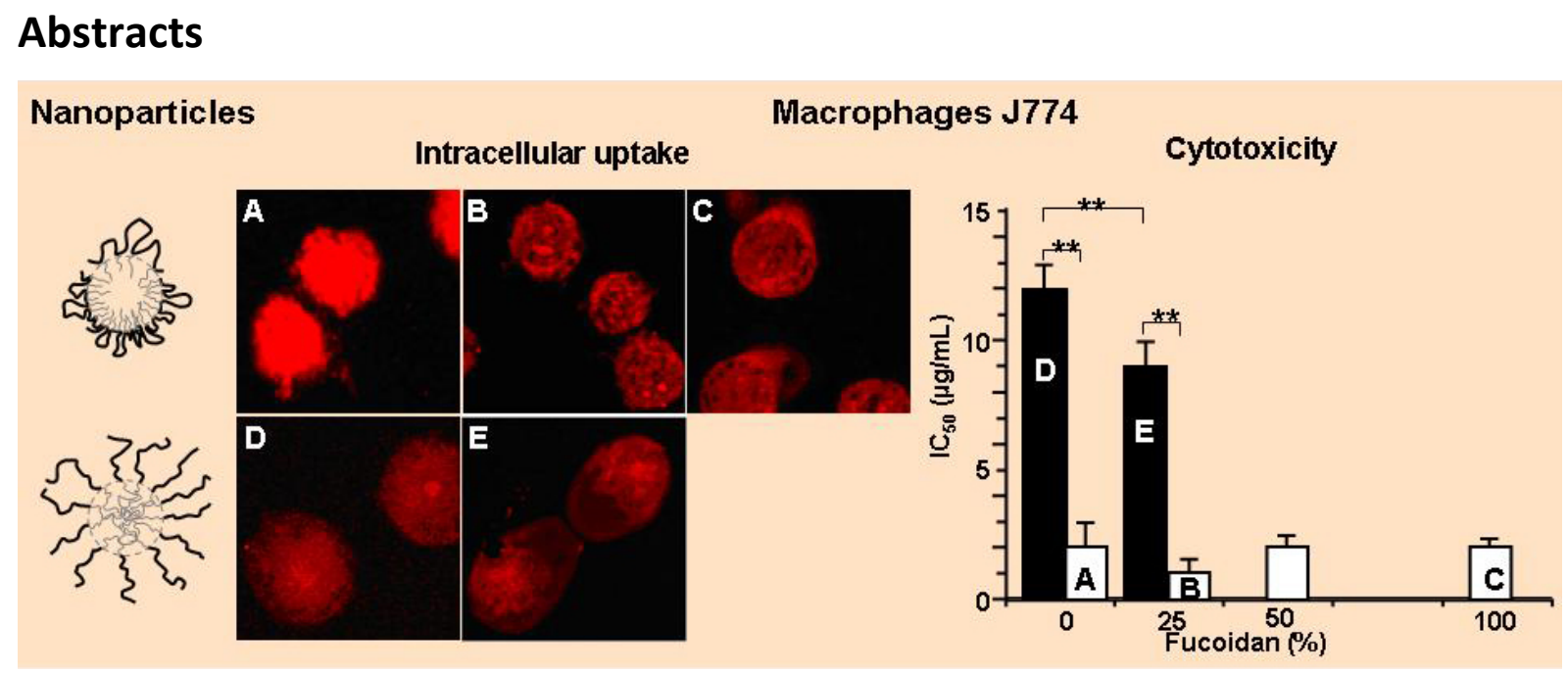

The aim was to synthesize and characterize fucoidan-coated poly(isobutylcyanoacrylate) nanoparticles. The nanoparticles were prepared by anionic emulsion polymerization (AEP) and by redox radical emulsion polymerization (RREP) of isobutylcyanoacrylate using fucoidan as a new coating material. The nanoparticles were characterized, and their cytotoxicity was evaluated in vitro on $\mathrm{J774}$ macrophage and NIH-3T3 fibroblast cell lines. Cellular uptake of labeled nanoparticles was investigated by confocal fluorescence microscopy. Results showed that both methods were suitable to prepare stable formulations of fucoidan coated PIBCA nanoparticles. Stable dispersions of nanoparticles were obtained by AEP with up to $100 \%$ fucoidan as coating material. By the RREP method, stable suspensions of nanoparticles were obtained with only up to $25 \%$ fucoidan in a blend of polysaccharide composed of dextran and fucoidan. The zeta potential of fucoidan-coated nanoparticles was decreased depending on the percentage of fucoidan. It reached the value of $-44 \mathrm{mV}$ for nanoparticles prepared by AEP with $100 \%$ of fucoidan. Nanoparticles made by AEP appeared more than four times more cytotoxic $\left(\mathrm{IC}_{50}\right.$ below $2 \mu \mathrm{g} / \mathrm{mL}$ ) on macrophages $\mathrm{J} 774$ than nanoparticles made by RREP (IC 50 above $9 \mu \mathrm{g} / \mathrm{mL}$ ). In contrast, no significant difference in cytotoxicity was highlighted by incubation of the nanoparticles with a fibroblast cell line. On fibroblasts, both types of nanoparticles showed similar cytotoxicity. Confocal fluorescence microscopy observations revealed that all types of nanoparticles were taken up by both cell lines. The distribution of the fluorescence in the cells varied greatly with the type of nanoparticles.

Keywords: poly(isobutylcyanoacrylate), fucoidan, core-corona nanoparticles, emulsion polymerization, cellular uptake 
Author manuscript from: Eur J Pharm Biopharm 79 (2011) 162-170.

\section{Introduction}

Polymer nanoparticles are considered as nanomedicine presenting high potential for diagnosis and therapeutical purposes with possibility to achieve site-specific drug delivery [1-3]. It is now well established that the in vivo fate of such types of nanocarriers is governed by their surface properties $[4,5]$.

Instead of PEG, polysaccharides are interesting materials to use making possible the obtaining of biomimetic nanoparticles with tunable surface properties. Their interest is growing considering the increased number of publications reporting the use of polysaccharides as coating material to design new nanoparticles for drug delivery during the last few years [6-12]. One reason can be that oligo and polysaccharides are spread at the surface of many living entities including eukaryote cells, bacteria, viruses where they play a major role in recognition and signaling mechanisms [13]. However, the incorporation of glycomics in nanomedicine appears challenging because of the wide variety of oligo and polysaccharides and the various biological functionalities they have. Although incorporating oligo and polysaccharide at the surface of a polymer nanoparticle was shown to be feasible, changes in the presentation of the polysaccharides on the nanoparticle surface was reported to induce dramatic changes in the biological response adding more in the challenge $[7,14,15]$.

Until now, dextran, chitosan and heparin were used as coating material of nanoparticles. Although dextran and chitosan have unknown specific biological properties in human, heparin has anti-clotting activities and is an inhibitor of the complement activation phenomenon. Interestingly, the biological activity of heparin was preserved after grafting at the nanoparticle surface [16]. Many other types of polysaccharides having biological activities may be interested to be used. Among them, fucoidan appears to be an excellent candidate. Fucoidan is a sulfated polysaccharide also named fucan or sulfated fucan. It is isolated from brown algae and displays many biological properties [17]. Its biological activities include antioxidant [18], anticoagulant [19-22], antiviral [23,24], antiinflammatory [20], anti-angiogenic [20], antitumor activities [25,26], inhibition of complement activation [27] and anti-proliferative effect on cells $[28,29]$. Fucoidan can also be applied for its ability to sequester toxic heavy metals such as $\mathrm{Cd}^{2+}, \mathrm{Cu}^{2+}, \mathrm{Zn}^{2+}, \mathrm{Pb}^{2+}, \mathrm{Cr}^{3+}$ and $\mathrm{Hg}^{2+}$ [30]. For pharmaceutical applications, it was used as scaffold for antibiotic immobilization [30] and as fucospheres in the treatment of dermal burns [31]. Interestingly, fucoidan can bind to type A I and II transmembrane glycoprotein receptors, found on the macrophage surface. These receptors, also called macrophage scavenger receptors (MSR), are modulators of the protein kinase signal transduction pathways, which regulate the atherogenesis-related inflammatory cytokines TNF and IL-1 [32,33]. Thus, fucoidan may be used to promote specific interactions of a drug carrier with macrophages. Such an approach could be worth to deliver large amount of antibiotics to macrophages infected by Mycobacterium tuberculosis. Another interesting property of fucoidan is its ability to adhere on Helicobacter pylori. This property, which was already proposed to reduce the adhesion of the bacteria on the gastric mucosa, could be used to target antibiotics to the bacteria cell [34].

The aim of the present work was to design new core-corona poly(isobutylcyanoacrylate) (PIBCA) nanoparticles with a corona composed of fucoidan and to investigate if the incorporation of fucoidan in the nanoparticle corona would be a relevant method to modulate interactions of the nanoparticles with cells including macrophages. In this study, the nanoparticles were prepared by two methods, the redox radical emulsion polymerization (RREP) and the anionic emulsion polymerization (AEP) of isobutylcyanoacrylate (IBCA). These methods provide with core-corona nanoparticles in which the polysaccharide corona is covalently linked to the PIBCA core of the nanoparticles [7]. The two methods give nanoparticles with a different conformation of the polysaccharide chains in the corona $[35,36]$ which were shown to affect interactions of the nanoparticles with proteins and cells $[8,37-$ 40]. 


\section{Materials and methods}

\subsection{Materials}

Isobutylcyanoacrylate (IBCA) was kindly provided as a gift by Henkel Biomedical (Dublin, Ireland). Dextran (Mw 66,900) was purchased from Sigma (Saint-Quentin Fallavier, France). Cerium (IV) (CelV) from cerium ammonium nitrate and tri-sodium citrate dihydrate were purchased from Fluka (Saint Quentin Fallavier, France). PolyFluor ${ }^{\circledR}$ 570: methacryloxyethyl thiocarbamoyl rhodamine B (N-[9-(2carboxy-x-methacryloxy-ethylthiolcarbamoyl-phenyl)-6-diethylamino-3H-xanthen-3-ylidene]- $\mathrm{N}$ ethyl-ethanaminium chloride) was supplied from Polyscience (Biovalley, Marne la Vallée, France). The brown algae Sargassum cymosum from which fucoidan was extracted and purified was collected on the south coast of Recife, PE, Brazil.

\subsection{Methods}

\subsubsection{Extraction and purification of fucoidan}

Fucoidan was extracted from brown algae Sargassum cymosum following the method adapted from Araújo et al. [41]. The algae samples were firstly triturated. Then the material was washed twice with acetone under magnetic stirring for $12 \mathrm{~h}$, in order to remove pigments and lipids. The solid residue was dried. Then it was dispersed in $\mathrm{NaCl} 0.15 \mathrm{M}$, the pH was adjusted to 8.0 with $\mathrm{NaOH}(0.1 \mathrm{M})$ and proteolysis was performed by adding papain $\left(15 \mathrm{mg} / \mathrm{g}\right.$ of solid residue) at $40{ }^{\circ} \mathrm{C}$. The mixture was maintained under magnetic stirring for $24 \mathrm{~h}$. Subsequently, the material was separated by filtration, the filtrate was centrifuged $\left(1000 \mathrm{rpm}, 4^{\circ} \mathrm{C}, 15 \mathrm{~min}\right)$, the supernatant was collected and lyophilized. Finally, the brown lyophilized powder obtained was dissolved in acetic acid (2\%) and purified by gel filtration on a Sepharose CL 4B column (Sigma-Aldrich, US) $(20 \mathrm{~cm} \times 2 \mathrm{~cm})$ using acetic acid $2 \%$ as an eluent. Fractions of $1 \mathrm{~mL}$ were collected and analyzed by spectrophotometer at $265 \mathrm{~nm}$. Fractions corresponding to the second elution peak ( $\mathrm{MW} 53 \mathrm{kDa}$ ) were pooled and lyophilized. The lyophilized powder was stored at room temperature until use.

\subsubsection{Preparation of fucoidan-coated poly(isobutylcyanoacrylate) nanoparticles}

The obtaining of fucoidan-coated nanoparticles was investigated by applying two emulsion polymerization methods $[7,42,45]$.

\subsubsection{Redox Radical Emulsion Polymerization (RREP)}

The methods described by Chauvierre et al. [35] and by Bertholon et al. [7] were adapted to prepare fucoidan-coated nanoparticles. A total amount of polysaccharide $(110 \mathrm{mg})$ including a blend of fucoidan and dextran in different proportions was dissolved in $4 \mathrm{~mL}$ of $0.2 \mathrm{M}$ nitric acid. The solution was placed under magnetic stirring at $40^{\circ} \mathrm{C}$ with nitrogen bubbling for $10 \mathrm{~min}$. Then, $1 \mathrm{~mL}$ of cerium (IV) ammonium-nitrate $\left(8 \times 10^{-2} \mathrm{M}\right)$ in $0.2 \mathrm{M}$ nitric acid and $250 \mu \mathrm{l}$ of the monomer IBCA were added successively under vigorous magnetic stirring $(1000 \mathrm{rpm})$. The polymerization system was then composed of $5 \mathrm{mg} / \mathrm{mL}$ of polysaccharides, $50 \mu \mathrm{L} / \mathrm{mL}$ of IBCA, $1.6 \times 10^{-2} \mathrm{M} \mathrm{Ce}^{\mathrm{IV}}$ in $0.2 \mathrm{M}$ nitric acid. The system was maintained under magnetic stirring for $1 \mathrm{~h}$. After cooling down to room temperature, 1 $\mathrm{mL}$ of an aqueous solution of trisodium citrate dihydrate $(1 \mathrm{M})$ was added to complex the remaining cerium ions. The nanoparticles prepared by this method were named RREP-Fuc-X\% with $\mathrm{X}$ indicating the percentage of fucoidan in the blend of polysaccharides used in the synthesis. To prepare fluorescent-labeled nanoparticles, the same procedure was followed except that $1 \mathrm{~mL}$ of a PolyFluor ${ }^{\circledR}$ 570 solution in acetonitrile $(4 \mathrm{mg} / \mathrm{mL})$ was added to the polymerization medium 2 min after the addition of the monomer (IBCA). 


\subsubsection{Anionic Emulsion Polymerization (AEP)}

The preparation of fucoidan-coated PIBCA nanoparticles by AEP was adapted from a previously reported method [42]. Briefly, fucoidan was first dissolved in pure water (5 mL). This solution was used in turn to dissolve dextran to reach a total amount of polysaccharide of $50 \mathrm{mg}$. Subsequently, the $\mathrm{pH}$ was decreased to 2.5 with $\mathrm{HCl}(1 \mathrm{~N})$. Then, $50 \mu$ of monomer IBCA were added drop wise under vigorous magnetic stirring. The system was left to polymerize for $3 \mathrm{~h}$ at room temperature. The polymerization system was composed of $10 \mathrm{mg} / \mathrm{mL}$ of polysaccharides including a blend of fucoidan and dextran at different proportions, $10 \mu \mathrm{L} / \mathrm{mL}$ of IBCA and of a diluted solution of $\mathrm{HCl}$ at $\mathrm{pH}$ 2.5. The nanoparticles prepared by this method were named AEP-Fuc-X\%, where the $X$ indicated the percentage of fucoidan in the blend of polysaccharides used in the synthesis of the nanoparticles. The labeled nanoparticles were prepared following the same method but by adding $50 \mu \mathrm{l}$ of a PolyFluor ${ }^{\circledR} 570$ solution in acetonitrile $(5 \mathrm{mg} / \mathrm{mL}) 5 \mathrm{~min}$ after the addition of the monomer (IBCA).

\subsubsection{Purification of nanoparticles}

All nanoparticle suspensions were purified by dialysis (Spectrapor ${ }^{\circledR}$ membrane 100,000 g/mol molecular weight cut off (MWCO), Biovalley, Marne la Vallée, France) twice against $1 \mathrm{~L}$ of distilled water for $30 \mathrm{~min}$ and once overnight. This dialysis was aimed to eliminate all reagents including polysaccharides that have not reacted during the nanoparticle synthesis. The purified suspensions were stored at $4{ }^{\circ} \mathrm{C}$ until use.

\subsubsection{Evaluation of particle size and zeta potential}

The diameter of the nanoparticles was measured at $25^{\circ} \mathrm{C}$ by quasi-elastic light scattering using a Malvern Zetasizer (Malvern Instrument, UK) operating at the angle of $90^{\circ}$. Samples were diluted in deionized water (Milli $\mathrm{Q}^{\circledR}$, Millipore, USA). The polydispersity index (PI) was evaluated to verify nanoparticle dispersion homogeneity (values close to zero indicate a homogeneous dispersion). The coefficient of variation (CV) was calculated from the following equation: CV $=\sigma / S D \times 100$ where, $\sigma$ was the polydispersity index and SD was the standard deviation.

The zeta potential of the nanoparticles was deduced from the electrophoretic mobility using a Malvern Zetasizer (Malvern Instrument, UK). Dilution of the nanoparticle suspensions was performed in $\mathrm{KCl} 1 \mathrm{mM}$. Results corresponded to the average of three determinations.

\subsubsection{Morphology of the nanoparticles}

The morphology of the nanoparticles was observed by transmission electron microscopy (TEM) (FEI, Tecnai20) at the Centro de Tecnologias Estratégicas do Nordeste (CETENE), Recife, PE, Brazil). The nanoparticle suspensions were diluted in filtrated water and spread on, a 200 mesh copper grid coated with Formvar ${ }^{\circ}$. The grid was dried in a desiccator before the observations.

\subsubsection{Cell culture}

Mouse cell lines were used in this study. They were chosen among a macrophage cell line the macrophages J774, and a fibroblast cell line NIH3T3 [43].

Macrophages $\mathrm{J} 774$ were grown in RPMI medium containing $10 \%$ decomplemented fetal bovine serum (FBS) (Gibco, Cergy-Pontoise, France) and antibiotics (penicillin $50 \mathrm{IU} / \mathrm{mL}$ - streptomycin 50 $\mathrm{UI} / \mathrm{mL}$ ), in a $5 \% \mathrm{CO}_{2}$ atmosphere at $37{ }^{\circ} \mathrm{C}$. Experiments were performed between the fourth and the fiftieth passages.. After evaluation of the concentration of viable cells using a hemocytometer, the concentration was adjusted to the required concentration for further experiments.

Fibroblasts NIH-3T3 cells were routinely grown in high glucose DMEM $(4.5 \mathrm{~g} / \mathrm{mL}$ ), 10\% FBS (Gibco, Cergy-Pontoise, France) and antibiotics (penicillin $50 \mathrm{IU} / \mathrm{mL}$ and streptomycin $50 \mathrm{UI} / \mathrm{mL}$ ), in a $5 \% \mathrm{CO}_{2}$ 
atmosphere at $37{ }^{\circ} \mathrm{C}$. Experiments were performed between the fourth and the fiftieth passages. Viable cells were counted in a hemocytometer to determine the concentration. Finally, the cell concentration was adjusted with culture medium to the required concentration in viable cells.

\subsubsection{Cytotoxicity studies}

Cytotoxicity of fucoidan-coated PIBCA nanoparticles was evaluated on $\mathrm{J774}$ macrophages and $\mathrm{NIH}$ $3 T 3$ cells using the MTT method [44]. The number of viable cells was determined by the estimation of their mitochondrial reductase activity. Briefly, cells were seeded onto 96-wells microtiter plates $(\mathrm{NIH}-$ 3T3: 2000 cells/well, $\mathbf{J 7 7 4}$ macrophages: 5000 cells/well) and grown in a humidified $5 \% \mathrm{CO}_{2}$ incubator at $37^{\circ} \mathrm{C}$. After overnight incubation, samples of nanoparticles $(10 \mu \mathrm{l})$ at concentrations ranging from 0 to $150 \mu \mathrm{g} / \mathrm{mL}$ were added to the medium for a $48 \mathrm{~h}$ incubation period. Subsequently, $20 \mu \mathrm{l}$ of MTT $(5 \mathrm{mg} / \mathrm{mL})$ were added in the cell culture medium and incubated for two hours. The medium was discarded and replaced by $200 \mu \mathrm{l}$ of DMSO to dissolve the insoluble crystals of formazan formed by living cells. The absorbance was read at $570 \mathrm{~nm}$ using a microplate reader (Labsystems Multiskan MS). Non-treated cells were used as a control. The cytotoxicity was expressed as the concentration required to inhibit fifty per cent of cell proliferation $\left(\mathrm{IC}_{50}\right)$. To evaluate the influence of the presence of fucoidan and also the preparation method of nanoparticles (AEP and RREP) on the cytotoxicity of PIBCA-nanoparticles on $\mathrm{J774}$ macrophages and NIH-3T3 fibroblasts, statistical analysis of variance (ANOVA) of three different assays was performed.

\subsubsection{Cellular uptake of fucoidan-coated nanoparticles}

The uptake of nanoparticles was investigated on $\mathrm{J} 774$ macrophages and NIH-3T3 fibroblasts using confocal fluorescence microscopy (Plateforme d'imagerie cellulaire, IFR 141, Univ. Paris Sud, Chatenay-Malabry, F-92296). Cells $\left(10^{5}\right.$ and $2 \times 10^{4}$ cells/well of $\mathrm{J774}$ macrophages and NIH-3T3 fibroblasts respectively) were grown for $48 \mathrm{~h}$ on glass coverslip placed in 12 wells culture plate. of J774 macrophages and NIH-3T3 fibroblastsThen fluorescent labeled-nanoparticles containing or not fucoidan at their surface were added in each well as follow: $50 \mu \mathrm{l}$ of AEP labeled-nanoparticles previously diluted in culture medium (320 $\mu$ l of nanoparticles suspension in $480 \mu \mathrm{l} / \mathrm{mL}$ to obtain 4 $\mu \mathrm{g} / \mathrm{mL}$ ) and $50 \mu \mathrm{l}$ of RREP labeled-nanoparticles previously diluted in culture medium ( $80 \mu \mathrm{l}$ of nanoparticle suspension in $720 \mu \mathrm{l} / \mathrm{mL}$ to obtain $4 \mu \mathrm{g} / \mathrm{mL}$ ). The volume of each well was completed to $1 \mathrm{~mL}$ to adjust the final concentration in nanoparticles to $0.2 \mu \mathrm{g} / \mathrm{mL}$. The plates were then incubated for $1,2,3,4$ and $24 \mathrm{~h}$ at $37^{\circ} \mathrm{C}$. After incubation, the cells were washed with culture medium and fixed by addition of $800 \mu \mathrm{l}$ of $4 \%$ paraformaldehyde in phosphate buffer saline (PBS) $(\mathrm{w} / \mathrm{v})$ for 20 minutes. The cells were washed with culture medium. In order to block the reactivity of the aldehyde, $1 \mathrm{~mL}$ of $50 \mathrm{mM}$ ammonium chloride $\left(\mathrm{NH}_{4} \mathrm{Cl}\right)$ was added and incubated for at least $10 \mathrm{~min}$. The cells were then washed again with culture medium. Finally, $10 \mu \mathrm{l}$ of Vectashield ${ }^{\circledR}$ mounting medium for fluorescence (Vector Laboratories, Inc., Burlingame, CA, USA) were laid on a microscope glass slide and coverslip with cells were over laid on this medium and sealed with nail polish. The mounted cells were kept at $4{ }^{\circ} \mathrm{C}$ until observations. Observations by optical and fluorescent microscopy (Leitz Diaplan microscope, France) were used to verify the shape of the cells and the absence of cell lysis.

The uptake of nanoparticles by the cells was then analyzed using confocal fluorescence microscopy (LSM 510 microscope, Zeiss, Germany). Confocal acquisitions were performed with a helium neon laser (excitation wavelength $543 \mathrm{~nm}$ ) and a long pass emission filter LP $560 \mathrm{~nm}$. Fluorescent images were obtained using a Plan Apochromat 63×, 1.4 numerical aperture oil immersion objective lens and the pinhole was set at 1.0 Airy unit $(0.8 \mu \mathrm{m}$ optical slice thickness). Stacks of images were collected every $0.41 \mu \mathrm{m}$ along the $\mathrm{z}$ axis. 12-bit numerical images were acquired with LSM 510 software version 3.2 . 


\section{Results and Discussion}

\subsection{Preparation of fucoidan-coated PIBCA nanoparticles}

Polymerizations of isobutylcyanoacrylate by AEP and RREP were investigated to design fucoidancoated PIBCA nanoparticles. To this aim, fucoidan was introduced at different proportions in a blend of polysaccharide composed of dextran and fucoidan in the polymerization medium. As indicated in Table 1, stable formulations of nanoparticles were obtained by the AEP method with all percentage of fucoidan. In contrast, by the RREP method, stable suspensions were only obtained with a low percentage of fucoidan ( 0 and $25 \%$ ) in the blend of polysaccharide. Suspensions of nanoparticles prepared with higher percentage of fucoidan ranging from 50 to $100 \%$ were unstable containing precipitates and aggregates.

The size of nanoparticles prepared by AEP was increased from $193 \pm 4 \mathrm{~nm}$ to $399 \pm 0.7 \mathrm{~nm}$, when the concentration of fucoidan was increased from 25 to $100 \%$ respectively. In contrast, in RREP nanoparticles the size decreased from $307 \pm 4 \mathrm{~nm}$ to $223 \pm 1 \mathrm{~nm}$ when preparations contained 0 and $25 \%$ fucoidan, respectively. The low polydispersity index and the low value of the CV (<5\%) indicated a narrow distribution of the particle size. The modifications in nanoparticle size between both methods and nature of polysaccharide were in agreement with those observed in previous work using other polysaccharides [7,9,37].

As shown in Table 1, the zeta potential of the nanoparticles obtained by the two methods became more negative when the amount of fucoidan was increased. The zeta potential reached the lowest value $(-44 \mathrm{mV}$ ) when the nanoparticles were prepared with $100 \%$ fucoidan (AEP-Fuc-100\%). These results can be explained by the negative charge of fucoidan. It also agreed with the value of zeta potential found in previous studies considering nanoparticles prepared with heparin, dextran-sulfate or with a blend of heparin and dextran [7,35,38]. Results from zeta potential measurements confirmed that fucoidan was located on the surface of PIBCA-nanoparticles. It is noteworthy that the zeta potential varied continuously from -5 to $-44 \mathrm{mV}$ when the composition in fucoidan was increased from 0 to $100 \%$ respectively. This result suggested that the nanoparticle surface was composed of a blend of fucoidan and dextran which composition depended on the composition used during synthesis.

Table 1. Physicochemical characteristics of PIBCA nanoparticles obtained by AEP and RREP with different ratios between fucoidan and dextran.

\begin{tabular}{lcllcc}
\hline PIBCA-NP & $\begin{array}{l}\text { Fucoidan:dextran } \\
\text { ratio }(\%)\end{array}$ & $\begin{array}{l}\text { Stability of } \\
\text { nanoparticle } \\
\text { suspensions* }\end{array}$ & $\begin{array}{l}\text { Size } \\
(\mathrm{nm})\end{array}$ & PI \pm SD & $\begin{array}{l}\text { Zeta potential } \\
(\mathrm{mV})\end{array}$ \\
\hline AEP-Fuc-0 & $0: 100$ & stable & $193 \pm 4$ & $0.14 \pm 0.01$ & $-5.53 \pm 1$ \\
AEP-Fuc-25 & $25: 75$ & stable & $195 \pm 2$ & $0.21 \pm 0.04$ & $-9.60 \pm 0.4$ \\
AEP-Fuc-50 & $50: 50$ & stable & $298 \pm 1$ & $0.25 \pm 0.03$ & $-12.0 \pm 1$ \\
AEP-Fuc-75 & $75: 25$ & stable & $298 \pm 0.4$ & $0.19 \pm 0.01$ & $-27.0 \pm 1$ \\
AEP-Fuc-100 & $100: 0$ & stable & $399 \pm 0.7$ & $0.07 \pm 0.07$ & $-44.2 \pm 1$ \\
\hline RREP-Fuc-0 & $0: 100$ & stable & $307 \pm 4$ & $0.09 \pm 0.04$ & $-6.39 \pm 0.1$ \\
RREP-Fuc-25 & $25: 75$ & stable & $223 \pm 1$ & $0.22 \pm 0.01$ & $-7.18 \pm 0.6$ \\
RREP-Fuc-50 & $50: 50$ & unstable & ---- & --- & ---- \\
RREP-Fuc-75 & $75: 25$ & aggregated & ---- & --- & --- \\
RREP-Fuc-100 & $0: 100$ & aggregated & ---- & --- & ---- \\
\hline
\end{tabular}

* The nanoparticles were considered as stable when the suspensions remained homogenous and did not show any sediment or precipitation over a period of 1 week after preparation. 
Fluorescent nanoparticles were synthesized by incorporating a fluorescent comonomer in the polymerization medium. The size of the fluorescent labeled nanoparticles was increased compared with those of the non fluorescent nanoparticles (Figure 1).
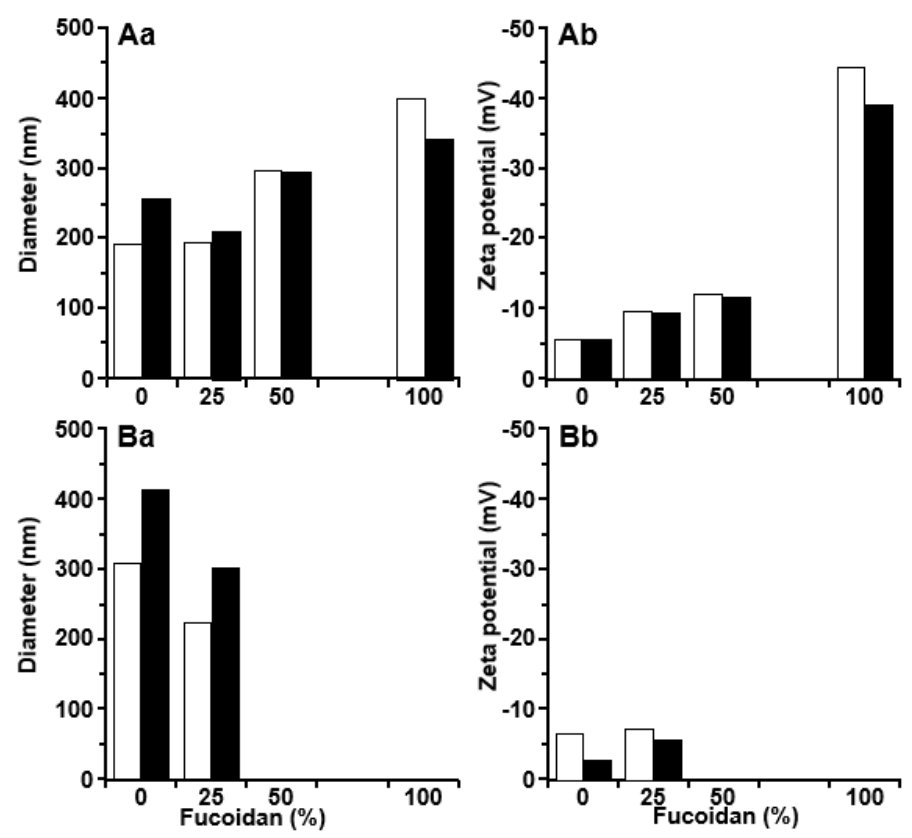

Figure 1. Size (a) and Zeta potential (b) of labeled (dark columns) and unlabeled nanoparticles (white columns) prepared by AEP (A) and RREP (B) with different percentages of fucoidan $(0,25,50$ and $100 \%)$.

In agreement with previously reported results considering the preparation of fluorescent chitosancoated nanoparticles [9], the increase in size observed was due to the incorporation of rhodamine, which is a large molecule, in the core of the nanoparticles. This was confirmed by the fact that zeta potentials of labeled nanoparticles were similar to those of the corresponding non labeled nanoparticles (Figure 1). At the $\mathrm{pH}$ of measurement, rhodamine is positively charged hence the fact that zeta potential of nanoparticles was unchanged after labeling indicated that rhodamine was not exposed at the nanoparticle surface but incorporated in the nanoparticle core. Results from both size and zeta potential measurements agreed with the method of labeling which was expected to promote the incorporation of the fluorescent probe in the nanoparticle core thanks to the copolymerization of the rhodamine-containing monomer with IBCA.

Nanoparticles observed by TEM showed a spherical shape independently of the method of preparation and of the fucoidan content (Figure 2). By increasing the magnification, the internal structure of the nanoparticles can clearly be highlighted. It showed an electron dense internal core surrounded by a corona which appeared far less dense to the electrons. These observations agreed with the expected core-corona structure for the nanoparticles synthesized by both method of synthesis.

Long-term stability was evaluated upon storage of nanoparticle suspensions at $+4^{\circ} \mathrm{C}$ over a period of 6 months (Figure 3). No significant changes in the size were detected over this period of time indicating that the nanoparticle suspensions were stable. It is noteworthy that neither a modification of the surface composition, nor the preparation method has affected the stability of the nanoparticle suspensions during storage. 

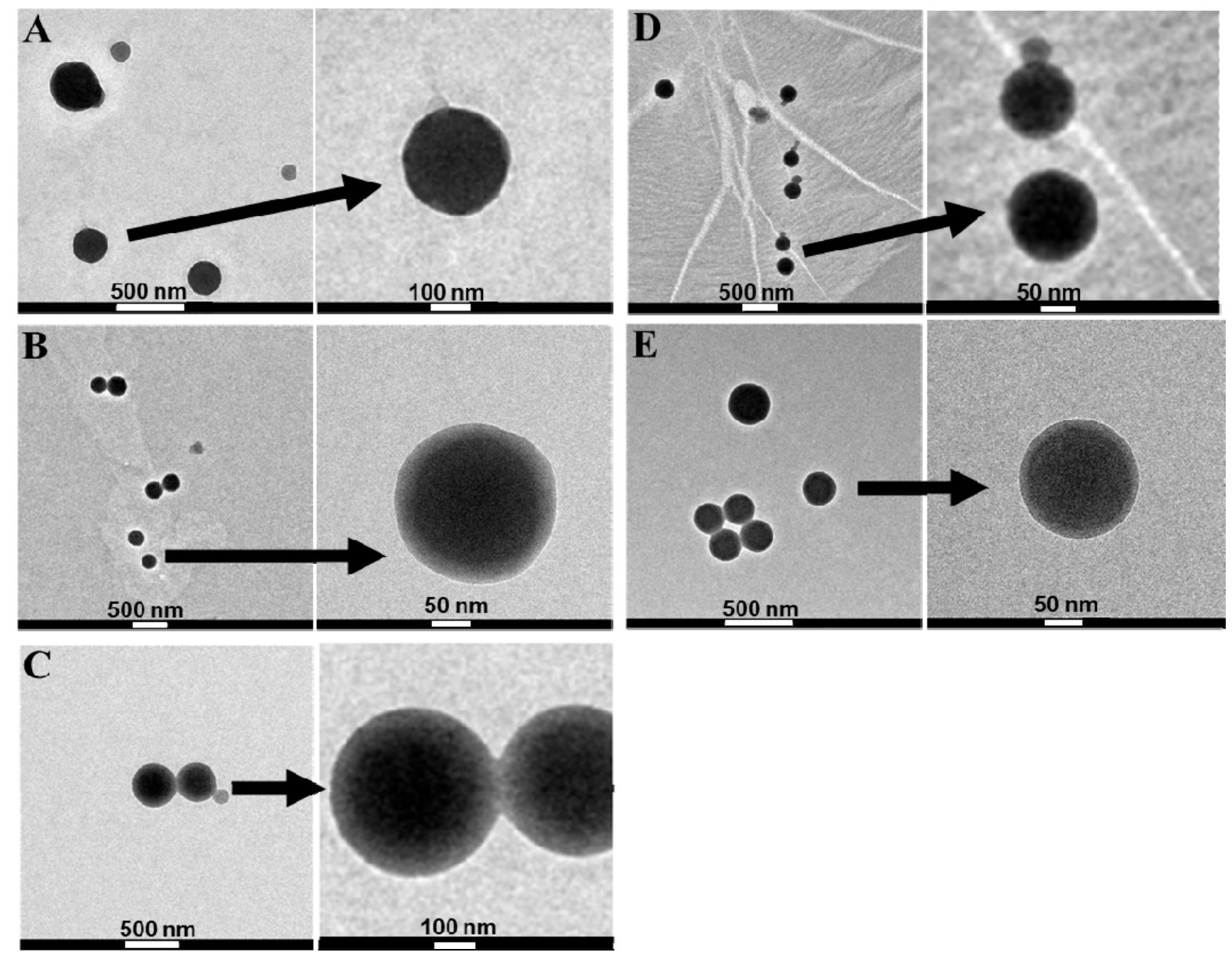

Figure 2. Transmission electron micrographs of (A) AEP, (B) AEP-Fuc-25, (C) AEP-Fuc-100, (D) RREP and (E) RREP-FUC-25 nanoparticles.

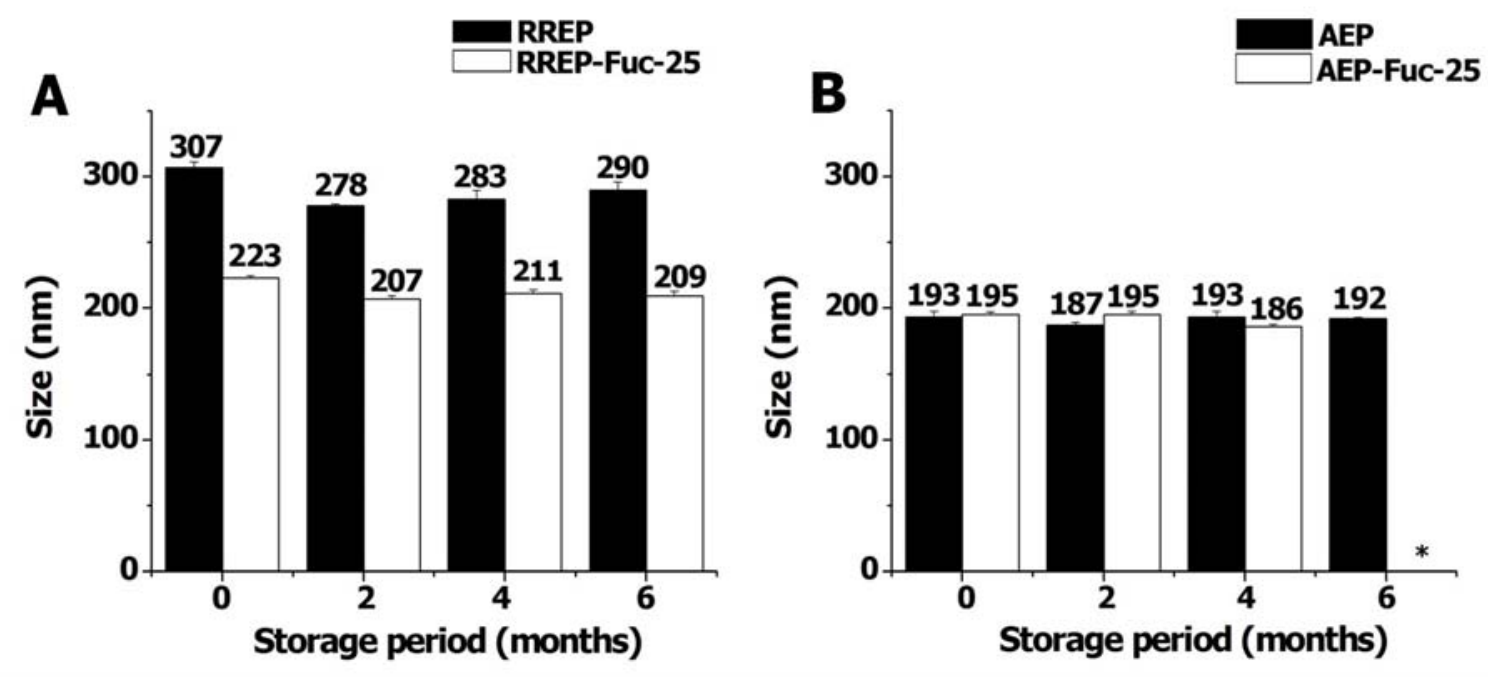

Figure 3. Size of PIBCA nanoparticles synthesized by RREP (A) and AEP (B) method after synthesis and over storage at $+4^{\circ} \mathrm{C}$ for a period of 6 months. Nanoparticles without fucoidan (black columns) and with $25 \%$ fucoidan (white columns). 


\subsection{Interactions of the nanoparticles with cells}

The rational behind the design of fucoidan-coated nanoparticles was to increase the affinity of the nanoparticles for macrophages thanks to a specific interaction with the MSR. Thus, the aim of this part of the study was to investigate whether or not the presence of fucoidan at the surface of nanoparticles actually promoted interactions of the nanoparticles with macrophages in comparison with non-macrophagic cells. Successful synthesis of different types of fucoidan-coated nanoparticles in the first part of this work made possible to investigate the influence of the fucoidan content and of the preparation method on the interactions of the nanoparticles with the cells. The method of preparation was an interesting parameter to consider as it influences the spatial arrangement of the polysaccharide chains at the nanoparticle surface [36]. This study was based on the evaluation of the cytotoxicity of the different types of nanoparticles on two cell lines: the macrophages $\mathbf{3 7 7 4}$ for the macrophagic cell line and the fibroblasts NIH3T3 which are nonprofessional phagocytes. In complement to the cytotoxicity evaluations, penetration of nanoparticles into cells was observed by confocal fluorescence microscopy.

In general, cytotoxicity of nanoparticles depends on the amounts of nanoparticles taken up by cells which in turn may depends on both the nanoparticle concentration added in the incubation medium and the incubation time [45]. In the present work, the cytotoxicity of the nanoparticles was evaluated after 48 hours of incubation with the cells and the cells were allowed to interact with different concentrations in nanoparticles during this fixed period of time. The figure 4 shows the $\mathrm{IC}_{50}$ of the different types of nanoparticles incubated with macrophages J774 (Figure 4A) and NIH 3T3 fibroblasts (Figure 4B). Standard deviations shown by the error bars indicate that the experiments performed with the macrophages $\mathrm{J} 774$ were more reproducible than those performed with the NIH 3T3 fibroblasts. This suggests that the mechanism of interactions of the nanoparticles with $\mathbf{7 7 7 4}$ cells was different than that involved in the interactions of the nanoparticles with the fibroblast cell line. The $I_{50}$ of AEP nanoparticles on the macrophages $J 774$ were low. It was not influenced by the content in fucoidan of the nanoparticles. This was in contrast with results expected from the assumption that fucoidan incorporated at the nanoparticle surface can promote interactions of nanoparticles with macrophages thanks to a specific recognition of this polysaccharide by the MSR exposed at the surface of macrophages [32,33 46]. The method of synthesis of the nanoparticles affected importantly the cytotoxicity of the nanoparticles on the macrophages $\mathbf{7 7 7 4}$. For instance, the AEP-Fuc-25 nanoparticles appeared seven folds more cytotoxic $\left(\mathrm{IC}_{50}=1.3 \pm 0.2 \mu \mathrm{g} / \mathrm{mL}\right)$ than the corresponding nanoparticles synthesized by the RREP method $\left(I C_{50}=9.6 \pm 0.5 \mu \mathrm{g} / \mathrm{mL}\right)$.

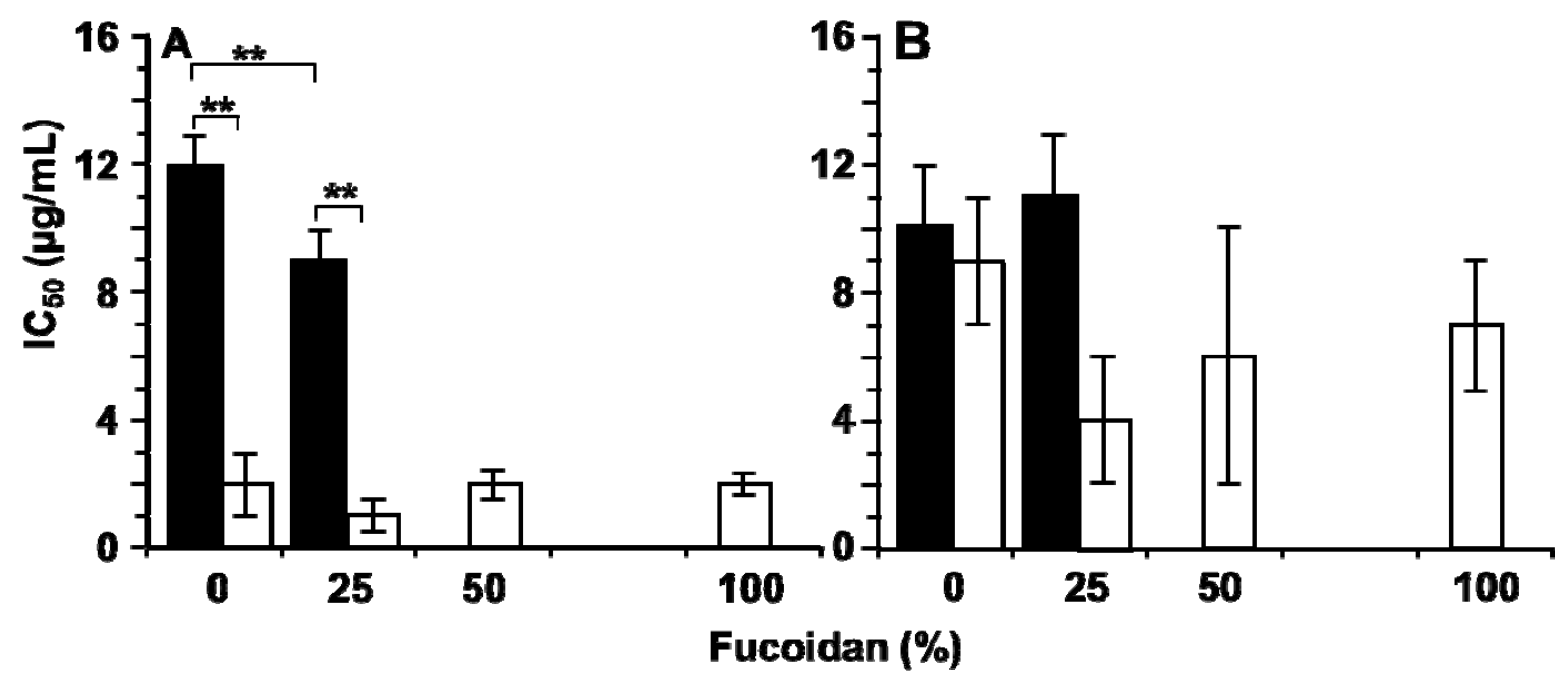

Figure 4. Cytotoxicity expressed as $I C_{50}$ of fucoidan coated PIBCA nanoparticles in $J 774$ macrophage cell line (A) and NIH-3T3 fibroblast cell line (B). RREP nanoparticles (dark columns) and AEP nanoparticles (white columns) $\left.{ }^{* *}\right)$ statistically different with $p<0.05 \ldots$ 
In contrast, no difference was highlighted evaluating the cytotoxicity of the AEP and RREP nanoparticles on the NIH $3 \mathrm{~T} 3$ fibroblasts. Most of the $\mathrm{IC}_{50}$ values ranged between $6 \pm 4 \mu \mathrm{g} / \mathrm{mL}$ and 11 $\pm 4 \mu \mathrm{g} / \mathrm{mL}$ with no significant difference after statistical analysis. It is noteworthy that the cytotoxicity levels shown by the nanoparticles on the NIH 3T3 fibroblasts were of the same order than that of the RREP nanoparticles on the macrophages $\mathrm{J774}$.

The fact that the cytotoxicity of the nanoparticles made by AEP was much above that of the nanoparticles made by the RREP on the $\mathrm{J774}$ cell line suggested that the macrophages $\mathrm{J774}$ were able to distinguish both types of nanoparticles. This could actually occur thanks to the difference in the polysaccharide chain conformation on the nanoparticle surface that resulted from the polymerization mechanism involved during the synthesis of the nanoparticles by AEP or RREP [8]. This assumption is supported by the fact that such a subtle difference in the surface structure between the AEP and RREP nanoparticles was already reported to induce dramatic differences in the response of biological systems. For instance, in another study, AEP nanoparticles coated with a different series of polysaccharides were reported to be far more cytotoxic than the corresponding RREP nanoparticles on a cancer cell line [15]. An opposite capacity to activate the complement system was reported comparing AEP and RREP nanoparticles prepared with either dextran or chitosan [8]. Finally, type of opsonin's which adsorbed on the polysaccharide-coated nanoparticles prepared by both methods of emulsion polymerization was specific to each type of nanoparticle [37].

To further understand how the different nanoparticles were interacting with cells, internalization of nanoparticles by cells was investigated by confocal fluorescence microscopy using fluorescent labeled nanoparticles. The nanoparticles were labeled by copolymerization of a fluorescent containing monomer with IBCA during the preparation of the nanoparticles. This labeling method allowed a stable incorporation of the fluorescent dye in the core of the nanoparticles. Observations were performed after different incubation times of the cells with fluorescent labeled nanoparticles at a concentration much below that of the $\mathrm{IC}_{50}$ shown by the more cytotoxic nanoparticles after 48 hours of incubation with cells. This concentration in nanoparticles was chosen to insure that the uptake of the nanoparticles by the cells was not influenced by eventual toxic effect on the time scale of the experiment.

Confocal fluorescence microscopy observations showed that all types of nanoparticles were taken up by $\mathrm{J774}$ macrophages in less than one hour of incubation. Considering each types of nanoparticles separately the increase of the intensity of the fluorescence in the cells with the incubation time indicating that more nanoparticles were taken up by the cells by prolonging the incubation time (Figure 5 and 6). From these observations, results from cytotoxicity evaluations cannot be explained by a simple difference of uptake of nanoparticles by cells. AEP nanoparticles and AEP- fucoidancoated nanoparticles were all taken up by $\mathrm{J} 774$ and by the NIH $3 T 3$ cells independently of their fucoidan content. Observations of the distribution of the fluorescence in the $\mathrm{J774}$ macrophages showed marked differences between AEP nanoparticles with no fucoidan and AEP-fucoidan-coated nanoparticles (Figure 5). After incubation of the cells with AEP nanoparticles with no fucoidan, the fluorescence was homogenously distributed throughout the cells. In contrast, the fluorescence accumulated in cells incubated with AEP-Fuc- 25 and AEP-Fuc-100 occurred as bright and concentrated punctuations disseminated in the cells. The difference in the localization of the fluorescence found in cells incubated with fucoidan-coated and non fucoidan-coated nanoparticles may be explained by different mechanisms of intracellular uptake and intracellular trafficking pathways. Regarding the RREP nanoparticles with and without fucoidan, they showed the same distribution of the fluorescence in the cells than the corresponding AEP nanoparticle counterparts. The results showed that the presence or the absence of fucoidan at the nanoparticle surface influence the way nanoparticles are interacting with the $\mathbf{J 7 4}$ cells and the fate of the nanoparticles within the cells. 


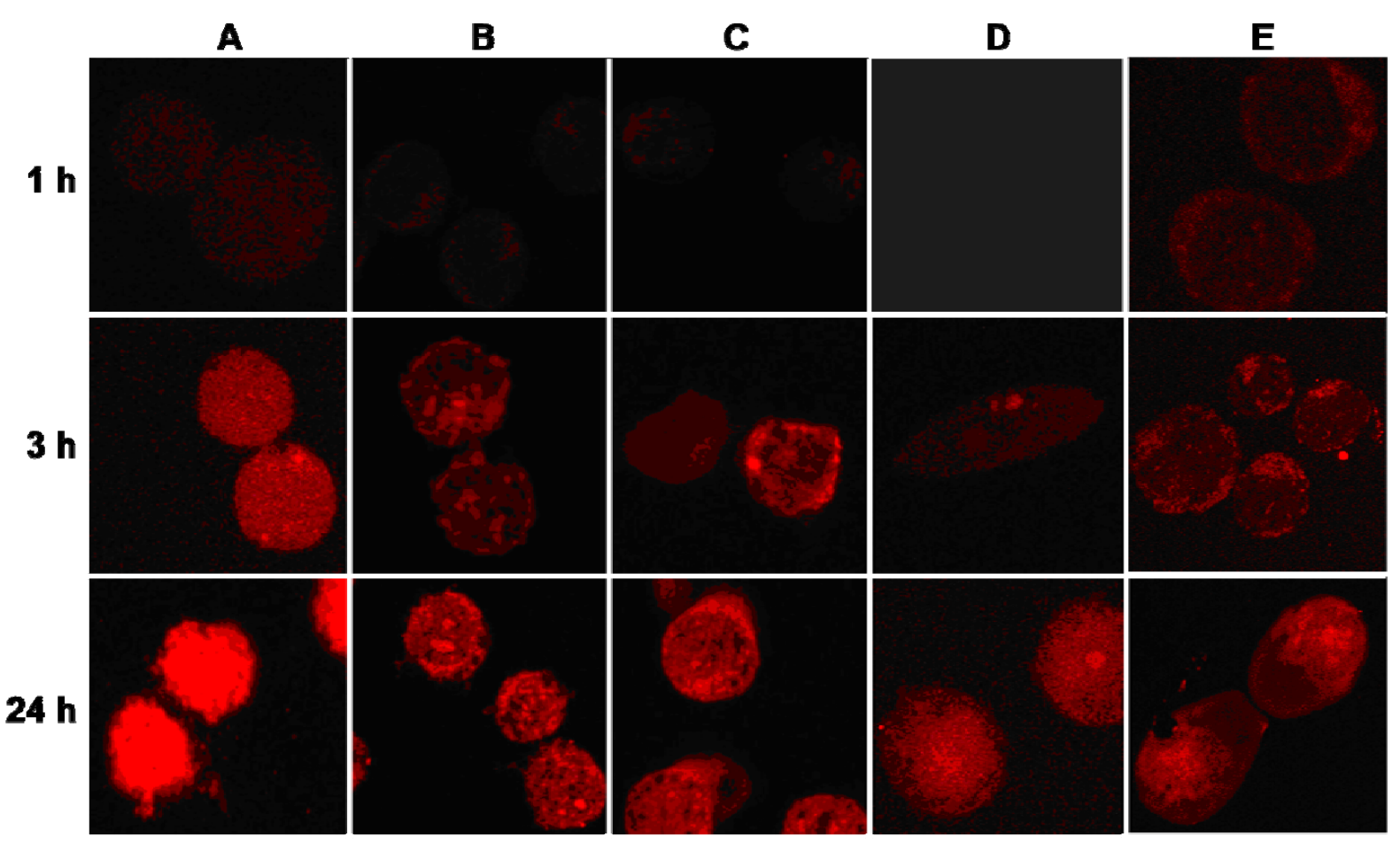

Figure 5. Confocal fluorescence microscopy of macrophage $J 774$ incubated with fluorescent nanoparticles (A: AEP, B: AEP-FUC-25, C: AEP-Fuc-100, D: RREP, and E: RREP-Fuc-25) at different incubation time (1, 3 and 24 hours). The confocal micrographs show an optical slice taken at the median plan of the cells. Image size: $73 \times 73 \mu \mathrm{m}$.

As already stated above, all types of nanoparticles were taken up by the NIH 3T3 fibroblasts (Figure 6). Although fibroblasts NIH-3T3 are not professional phagocytes, our observations agreed with those of other publications having reported that these fibroblasts were able to internalize polymeric nanoparticles $[47,48]$. The NIH 3T3 cells showed a specific behavior after incubation with the AEP nanoparticles while almost no differences were highlighted after incubation with the other nanoparticles (AEP-Fuc-25, AEP-Fuc-100, RREP, RREP-Fuc-25). Indeed, after 24 hours of incubation with the AEP nanoparticles prepared without fucoidan, the cells have lost their typical elongated morphology. They appeared circular and showed vacuoles in the cytoplasm (Figure 6A). This indicated that the structure of the actin fibers of the cytoskeleton was lost [49]. This change in morphology was unexpected from the results of the cytotoxicity (Figure 4). However, it was reported in the literature that such a modification of cell morphology did not interfere with the cell viability on the time scale of the present study [50]. In contrast to this previous finding, the typical elongated morphology of the NIH 3T3 cells was well preserved after incubation of the fibroblasts with the other nanoparticles.

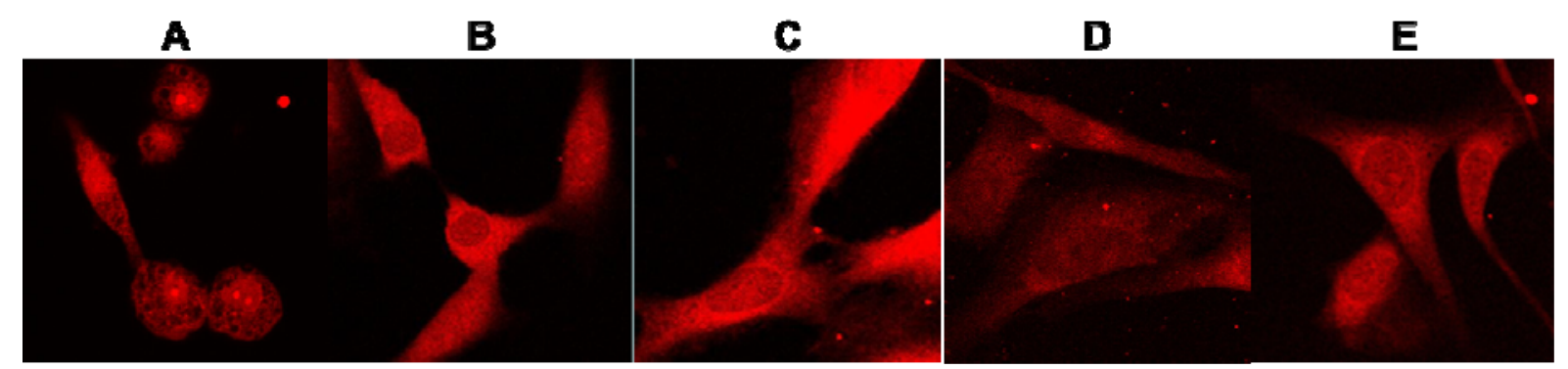

Figure 6. Confocal fluorescence microscopy of fibroblasts NIH-3T3 incubated for 24 hours with fluorescent nanoparticles (A: AEP, B: AEP-Fuc-25, C: AEP-Fuc-100, D: RREP, and E: RREP-Fuc-25). The confocal micrographs show an optical slice taken at the median plan of the cells. Image size: $73 \times 73$ $\mu m$ 
Except this difference in morphology, the distribution of the fluorescence in the cell was very similar comparing the different types of nanoparticles. As shown on figure 6 the fluorescence found in the cells appeared more or less diffused. This is in contrast with results from the observations made after incubation of the $\mathbf{J 7 7 4}$ macrophages with nanoparticles prepared by the AEP method. Indeed, with the NIH 3T3, no obvious difference appeared between the fucoidan-coated and the non-fucoidancoated nanoparticles. This result suggest that nanoparticles are interacting and penetrating in the NIH 3T3 cells through mechanisms which are independent of the presence and of the absence of fucoidan at the nanoparticle surface. This was a main contrast with what was observed with the J774 cell line for which the presence of fucoidan at the nanoparticle surface changed the distribution of the fluorescence within the cells suggesting that fucoidan-coated nanoparticles may enter the cells by a different pathway than nanoparticles without fucoidan in the coating layer.

\section{Conclusions}

Different types of nanoparticles coated with fucoidan were obtained by emulsion polymerization of IBCA. The maximum amount of fucoidan incorporated in nanoparticles without compromising the stability of the dispersion depended on the type of polymerization (AEP vs RREP). Cytotoxicity and intracellular distribution of the nanoparticles in cells were affected by many of the studied parameters. This work gave first evidence that interactions of nanoparticles with macrophages can be modulated by the introduction of fucoidan in the nanoparticle corona. Further studies are now needed to elucidate mechanisms of intracellular uptake and pathways of intracellular trafficking. Other studies are required to understand why cytotoxicity of AEP and RREP nanoparticles appeared so different on macrophages.

\section{Acknowledgments}

The authors are deeply grateful to Dr. K. Broadley (Henkel Biomedical, Ireland) for his kind support providing the IBCA used to prepare the nanoparticles. The authors also thank Mr. Padrón and Mr. Rangel (Centro de Tecnologias Estratégicas do Nordeste (CETENE), Recife, Brazil) for their precious technical assistance on electron microscopic analysis. LIRA, M.C.B thanks the French-Brazilian Agreement Capes-Cofecub (\# 535/06) for a PhD scholarship. Vauthier C. thanks CNPq support (\#401979/2008-3), Ponchel G. and Santos-Magalhães N. thanks French-Brazilian Agreement CapesCofecub (\# 535/06).

\section{References}

[1] P. Couvreur, C. Vauthier, Nanotechnology: Intelligent design to treat complex desease. Pharm. Res. 23 (2006) 1417-1450.

[2] S.D. Li, L. Huang Pharmacokinetic and biodistribution of nanoparticles. Mol. Pharm. 5 (2008) 496-504.

[3] O.C. Farokhzad, R. Langer, Impact of nanotechnology on drug delivery. ACS Nano. 27 (2009) 1620.

[4] A. Vonarbourg, C. Passirani, P. Saulnier, J.P.; Benoit, Parameters influencing the stealthiness of colloidal drug delivery systems. Biomaterials. 27 (2006) 4356-4373.

[5] M.A. Dobrovolskaia, P. Aggarwal, J.B. Hall, S.E. McNeil, Preclinical studies to understand nanoparticle interaction with the immune system and its potential effects on nanoparticle biodistribution. Mol. Pharm. 5 (2008) 487-495.

[6] C. Lemarchand, R. Gref, P. Couvreur, Polysaccharide-decorated nanoparticles. Eur. J. Pharm. Biopharm. 58 (2004) 327-341.

[7] I. Bertholon, C. Vauthier, D. Labarre, Characterization of Dextran-Poly(isobutylcyanoacrylate) Copolymers Obtained by Redox Radical and Anionic Emulsion Polymerization. Macromolecules 39 (2006) 3559-3567. 
[8] I. Bertholon, C. Vauthier, D. Labarre, Complement activation by core-shell poly(isobutylcyanoacrylate)-polysaccharide nanoparticles: influences of surface morphology, length, and type of polysaccharide. Pharm. Res. 23 (2006) 1313-1323.

[9] I. Bravo-Osuna,G. Ponchel, C. Vauthier, Tuning of shell and core characteristics of chitosandecorated acrylic nanoparticles. Eur. J. Pharm. Sci. 30( 2007) 143-154.

[10] M. He, Z. Zhao, L. Yin, C. Tang, C. Yin, Hyaluronic acid coated poly(butyl cyanoacrylate) nanoparticles as anticancer drug carriers. Int. J. Pharm. 373 (2009) 165-173.

[11] H. De Martimprey, C. Vauthier, C. Malvy, P. Couvreur, Polymer nanocarriers for the delivery of small fragments of nucleic acids: Oligonucleotides and siRNA. Eur. J. Pharm. Biopharm. 71 (2009) 490-504.

[12] M. Wu, E. Dellacherie, A. Durand, E. Marie, Poly(n-butyl cyanoacrylate) nanoparticles via miniemulsion polymerization (1): Dextran-based surfactants. Coll. Surf. B: Biointerfaces. 69 (2009) 141-146.

[13] J. Sheen, L. Zhou, J. Jyun-Chyun, Sugars as signaling molecules. Curr. Opin. Plant Biol. 2 (1999) 410-418.

[14] C. Lemarchand, R. Gref, C. Passirani, E. Garcion, B. Petri, R.H. Müller, D. Costantini, P. Couvreur, Influence of polysaccharide coating on the interactions of nanoparticles with biological systems. Biomaterials. 27 (2006) 108-118.

[15] C. Chauvierre, L. Leclerc, D. Labarre, M. Appel, M.C. Marden, P. Couvreur, C. Vauthier, Enhancing the tolerance of poly(isobutylcyanoacrylate) nanoparticles with a modular surface design. Int. J. Pharm. 338 (2007) 327-332.

[16] C. Chauvierre, M.C. Marden, C. Vauthier, D. Labarre, P. Couvreur, L. Leclerc, Heparin coated poly(alkylcyanoacrylate) nanoparticles coupled to hemoglobin: a new oxygen carrier Biomaterials 25 (2004) 3081-3086.

[17] B. Li, F. Lu, X. Wei, R. Zhao, Fucoidan: Structure and bioactivity. Molecules. 13 (2008) 1671-1695.

[18] J. Wang, Q. Zhang, Z. Zhang, Z. Li, Antioxidant activity of sulfated polysaccharide fractions extracted from Laminaria japonica. Int. J. Biol. Macromol. 42 (2008) 127-132.

[19] C.F. Becker, J.A. Guimarães, P.A.S. Mourão, H. Verli, Conformation of sulfated galactan and sulfated fucan in aqueous solutions: Implications to their anticoagulant activities. J. Mol. Graph. Model. 26 (2007) 391-399.

[20] A. Cumashi, N.A. Ushakova, M.E. Preobrazhenskaya, A. D'Incecco, A. Piccoli, L. Totani, N. Tinari, G.E. Morozevich, A.E. Berman, M.I. Bilan, A. I. Usov, N.E. Ustyuzhanina, A.A. Grachev, C.J. Sanderson, M. Kelly, G.A. Rabinovich, S. lacobelli, N.E. Nifantiev, A comparative study of the anti-inflammatory, anticoagulant, antiangiogenic, and antiadhesive activities of nine different fucoidans from brown seaweeds. Glycobiology. 17 (2007) 541-552.

[21] S.J. Yoon, Y.R. Pyun, J.K. Hwang, P.A.S. Mourão, A sulfated Fucoidan from the brown alga Laminaria cichorioides has mainly heparin cofactor II-dependent anticoagulant activity Carbohydrate Res. 342 (2007) 2326-2330.

[22] N.A. Ushakova, G.E. Morozevich, N.E. Ustyuzhanina, M.I. Bilan, A.I. Usov, N.E. Nifantiev, M. E.; Preobrazhenskaya, Anticoagulant activity of fucoidans from brown algae. Biomed. Chem. 3 (2009) 77-83.

[23] K. Hayashi, T. Nakano, M. Hashimoto, K. Kanekiyo, T. Hayashi, Defensive effects of a fucoidan from brown alga Undaria pinnatifida against herpes simplex virus infection. Int. Immunopharm. 8 (2008) 109-116 (2008).

[24] K.I.P.J. Hidari, N. Takahashi, M. Arihara, M. Nagaoka, K. Morita, T. Suzuki, Structure and antidengue virus activity of sulfated polysaccharide from a marine alga. Biochem. Biophys. Res. Commun. 376 (2008) 91-95.

[25] M. Ellouali, C. Boisson-Vidal, P. Durand, J. Jozefonvicz, Antitumor activity of low molecular weight fucoidans extracted from brown seaweed Ascphyllum nodosum. Anticancer Res. 13 (1993) 2011-2020. 
[26] H. Itoh, H. Noda, H. Amano, C. Zhuaug, T. Mizuno, Antitumor-activity and immunological properties of mariane algal polysaccharides, especially fucoidan, prepared from SargassumThunbergii of phaeophyceae. Anticancer Res. 13 (1993) 2045-2052.

[27] T.N. Zvyagintseva, N.M. Shevchenko, I.V. Nazarova, A.S. Scobun; P.A. Lukyanov, L.A. Elyakova, Inhibition of complement activation by water-soluble polysaccharides of some far-eastern brown seaweeds. Comp. Biochem Physiol. Part C. 126 (2000) 209-215.

[28] M. Ellouali, C. Boisson-Vidal, J. Jozefonvicz, Antiproliferative effect an interaction of Fucoidans with cells. Coll. Surf. B: Biointerfaces. 2 (1994) 305-314.

[29] D. Logeart, S. Prigent-Richard, J. Jozefonvicz, D. Letourneur, Fucans, sulfated polysaccharides extracted from brown seaweeds, inhibit vascular smooth muscle cell proliferation. I. Comparison with heparin for antiproliferative activity, binding and internalization. Eur. J. Cell Biol. 74 (1997) 376-384.

[30] T.A. Davis, B. Volesky, A. Mucci, A review of the biochemistry of heavy metal biosorption by brown algae. Water Res. 37 (2003) 4311-4330.

[31] A.D. Sezer, E. Cevher, F. Hatipoğlu, Z. Oğurtan, A.L.;Baş, A.D. Akbuğa, The use of fucosphere in the treatment of dermal burns in rabbits. Eur. J. Pharm. Biopharm. 69 (2008) 189-198.

[32] H.Y. Hsu, S.L. Chiu, M.H. Wen, K.Y. Chen, K.F. Hua, Ligands of macrophage scavenger receptor induce cytokine expression via differential modulation of protein kinase signaling Pathways. J. Biol. Chem. 276 (2001) 28719-28730.

[33] W.S. Kim, C.M. Ordija, M.W. Freeman, Activation of signaling pathways by putative scavenger receptor class A (SR-A) ligands requires CD14 but not SR-A. Biochem. Biophys. Res. Commun. 310 (2003) 542-549.

[34] H. Shibata, M. Limuro, N. Uchiya, T. Kawamori, M. Nagaoka, S. Ueyama, S. Hashimoto, T. Yokokura, T. Sujimura, K. Wakabayashi, Preventive effects of Cladosiphon fucoidan against Helicobacter pylori infection in mongolian gerbils. Helicobacter 8 (2003) 59-65.

[35] C. Chauvierre, D. Labarre, P. Couvreur, C. Vauthier, Novel Polysaccharide-Decorated Poly(Isobutyl Cyanoacrylate) Nanoparticles. Pharm. Res. 20 (2003) 1786-1793.

[36] I. Bertholon, H. Hommel, D. Labarre, C. Vauthier, Properties of polysaccharides grafted on nanoparticles investigated by EPR. Langmuir 22 (2006) 5485-5490.

[37] D. Labarre, C. Vauthier, C. Chauvierre, B. Petri, R.H. Müller, M.M. Chehimi, Interactions of blood proteins with poly(isobutylcyanoacrylate) nanoparticles decorated with a polysaccharidic brush. Biomaterials. 26 (2005) 5075-5084.

[38] C. Chauvierre, L. Leclerc, D. Labarre, M. Appel. M.C. Marden, P. Couvreur, C. Vauthier. Enhancing the tolerance of poly(isobutylcyanoacrylate) nanoparticles with a modular surface design. Int J Pharm. 338 (2007) 327-332.

[39] C. Vauthier, P. Lindner, B. Cabane. Configuration of bovine serum albumin adsorbed on polymer particles with grafted dextran corona. Colloids Surf B Biointerfaces. 69 (2009) 207-215.

[40] C. Vauthier, B. Persson, P. Lindner, B. Cabane. Protein adsorption and complement activation for di-block copolymer nanoparticles. Biomaterials. 32 (2011) 1646-1656.

[41] P.M. Araújo, G.B. Oliveira, C.R. Córdula, E.L. Leite, L.B. Carvalho Jr. M.P.C. Silva, Sulfated fucan as support for antibiotic immobilization. Braz. J. Med. Biol. Res. 37 (2004) 301-305.

[42] P. Couvreur, B. Kante, M. Roland, P. Guiot, P. Bauduin, P. Speiser, Polycyanoacrylate nanocapsules as potential lysosomotropic carriers: preparation, morphological and sorptive properties. J. Pharm. Pharmacol. 31 (1979) 331-332.

[43] H. Hillaireau, P. Couvreur, Nanocarriers' entry into the cell: relevance to drug delivery. Cell Mol. Life Sci. 66 (2009) 2873-2896.

[44] M.C. Alley, D.A. Scudiero, A. Monks, M.L. Hursey, M.J. Czerwinski, D.L. Fine, B.J. Abbot, J.G. Mayo, R.H. Shoemaker, M.R. Boyd, Feasibility of drug screening with panels of human tumor cell lines using a microculture tetrazolium assay. Cancer Res. 48 (1988) 589-601.

[45] V. Mailänder, K. Landfester. Interaction of nanoparticles with cells. Biomacromolecules. 10 (2009) 2379-2400. 
[46] T. Nakamura, H. Suzuki, Y. Wada, T. Kodama, T. Doi, Fucoidan induces nitric oxide production via p38 mitogen-activated protein kinase and NF-jB-dependent signaling pathways through macrophage scavenger receptors. Biochem. Biophys. Res. Commun. 343 (2006) 286-294.

[47] N. Toub, J.R. Bertrand, A. Tamaddon, H. Elhamess, H. Hillaireau, A. Maksimenko, J. Maccario, C. Malvy, E. Fattal, P. Couvreur, Efficacy of siRNA Nanocapsules Targeted Against the EWS-Fli1 Oncogene in Ewing Sarcoma. Pharm. Res. 23 (2006) 892-900.

[48] H. De Martimprey, J.R. Bertrand, C. Malvy, P. Couvreur C. Vauthier, New Core-Shell Nanoparticules for the Intravenous Delivery of siRNA to Experimental Thyroid Papillary Carcinoma. Pharm. Res. 27 (2010) 498-509.

[49] M.J. Dalby, M.O. Riehle, D.S. Sutherland, H. Agheli, A.S.G. Curti, Changes in fibroblast morphology in response to nano-columns produced by colloidal lithography. Biomaterials 25 (2004) 5415-5422

[50] A.K. Gupta, M. Gupta, S.J. Yarwood, A.S.G. Curtis, Effect of cellular uptake of gelatin nanoparticles on adhesion, morphology and cytoskeleton organisation of human fibroblasts. J. Control. Rel. 95 (2004) 197- 207. 